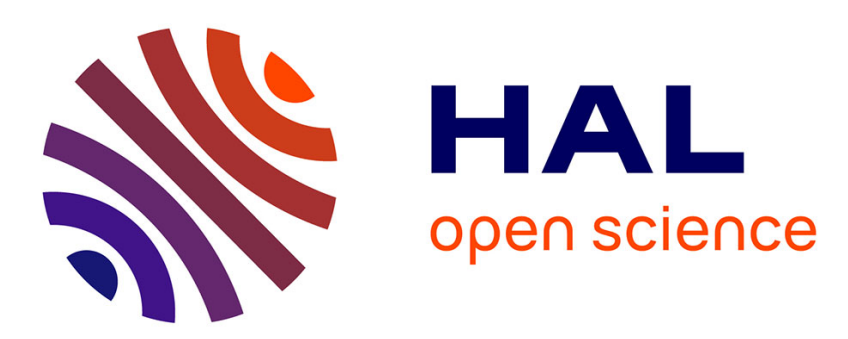

\title{
Species substitution for carbon storage: Sessile oak versus Corsican pine in France as a case study
}

P. Vallet, Céline Meredieu, I. Seynave, T. Bélouard, J.F. Dhote

\section{To cite this version:}

P. Vallet, Céline Meredieu, I. Seynave, T. Bélouard, J.F. Dhote. Species substitution for carbon storage: Sessile oak versus Corsican pine in France as a case study. Forest Ecology and Management, 2009, 257 (4), p. 1314 - p. 1323. 10.1016/j.foreco.2008.11.034 . hal-00454540

\author{
HAL Id: hal-00454540 \\ https://hal.science/hal-00454540
}

Submitted on 8 Feb 2010

HAL is a multi-disciplinary open access archive for the deposit and dissemination of scientific research documents, whether they are published or not. The documents may come from teaching and research institutions in France or abroad, or from public or private research centers.
L'archive ouverte pluridisciplinaire HAL, est destinée au dépôt et à la diffusion de documents scientifiques de niveau recherche, publiés ou non, émanant des établissements d'enseignement et de recherche français ou étrangers, des laboratoires publics ou privés. 
Forest Ecology and Management, 2009, 257:4 1314-1323

doi:10.1016/j.foreco.2008.11.034

Species substitution for carbon storage:

sessile oak versus Corsican pine in France as a case study

Patrick VALLET ${ }^{1, *}$, Céline MEREDIEU ${ }^{2}$, Ingrid SEYNAVE ${ }^{3}$, Thierry BÉLOUARD ${ }^{4}$, JeanFrançois DHÔTE ${ }^{3,5}$

(1) Cemagref, UR Ecosystèmes Forestiers, Domaine des Barres, F-45290 Nogent-sur-Vernisson, France.

(2) INRA, UMR1202 Biogeco, F-33612 Cestas, France.

(3) INRA, UMR1092, 14 rue Girardet, CS4216, F-54042 Nancy, France.

(4) Inventaire Forestier National, 62 rue de Laseppe, F-33000 Bordeaux, France.

(5) Office National des Forêts, Département Recherche, F-77300 Fontainebleau, France

(*) Corresponding author: e-mail address patrick.vallet@,cemagref.fr,

Phone: +33238950354

Fax: +33238950346 


\begin{abstract}
Species choice is potentially an important management decision for increasing carbon stocks in forest ecosystems. The substitution of a slow-growing hardwood species (Quercus petraea) by a fastgrowing conifer plantation (Pinus nigra subsp. laricio) was studied in central France. Simulations of carbon stocks in tree biomass were conducted using stand growth models Fagacées for sessile oak and $P N L$ for Corsican pine. The changes in soil carbon were assessed using the Century model and data from two European soil monitoring networks: 16x16 km grid and RENECOFOR. Carbon in wood products was assessed with life cycle analysis and lifespans of final products. However, only carbon stocks and their variation were accounted for: effects of energy-consuming materials or fossil fuel substitution are excluded from the analysis. To compare the growth of these two types of forest stands, an important part of the study was to assess the productivity of both species at the same site, using National Forest Inventory data.
\end{abstract}

Simulations showed that $(i)$ this species substitution would lead to an additional carbon storage of $1.6 \mathrm{tC} / \mathrm{ha} / \mathrm{yr}$ with the conifer plantation during its first rotation (64 years) (ii) at steady state, the time-averaged carbon stock of the conifer plantation over the whole rotation would be $42 \mathrm{tC} / \mathrm{ha}$ to 47 tC/ha lower than that of the hardwood even-aged forest, depending on applied silvicultural scenarios. The time-averaged carbon stocks including vegetation, soil and wood products are $221 \mathrm{tC} / \mathrm{ha}$ for sessile oak, and around $175 \mathrm{tC} / \mathrm{ha}$ for Corsican pine. The amount of carbon stored in wood products is low compared to the total carbon stock ( $5 \%$ for sessile oak, 8 to $8.5 \%$ for Corsican pine), mainly due to important losses during early wood processing, and to the short lifespans of wood products compared to the rotation length of forest stands.

\title{
Keywords
}

Carbon stock, species substitution, Quercus petraea, Pinus nigra subsp. laricio, biomass, soil, wood product 


\section{Introduction}

Forest ecosystems can play a role in carbon storage to reduce atmospheric carbon dioxide in several ways. It is possible (i) to increase the areas covered by forests in order to increase the carbon stocks in terrestrial biomes, (ii) to change forest management options to store more carbon in already forested areas, and, (iii) to substitute fossil fuel by biomass or energy-intensive materials by construction timber (Cannell, 1995; Lindner, 1998). Species selection is one of the forest management options for increasing carbon stocks. Cannell (1996) pointed out that on the one hand fast-growing plantations would accumulate carbon more rapidly than slow-growing forest up to the time of harvest. On the other hand, for long time storage, slow-growing forests would be preferable as they have a higher time-averaged carbon stocks. Several studies have shown that species substitution induced by replacing primary or old-growth forests by plantations leads to a loss of carbon (Cropper and Ewel, 1987; Fleming and Freedman, 1998; Schroth et al., 2002; Erb, 2004), even when wood used in building structures is included in the models (Harmon et al., 1990). Beyond these general results, there is a lack of information about the carbon storage impact of species substitution in a large range of realistic situations of site productivities and silvicultural options.

Substituting species will imply changes in carbon stocks in both belowground and aboveground vegetation, but also in soil organic matter and in wood products. Carbon in wood products is complicated to assess (Karjalainen et al., 1994; Liski et al., 2001). Nevertheless, it has to be to taken into account since products from two different species have specific market destinations and lifespans (Dewar and Cannell, 1992; Karjalainen et al., 2002; Marland and Marland, 2003). The soil carbon content and changes with silviculture are also difficult to estimate as show e.g. the review of Yanai et al. (2003). But the changes in soil carbon could be high (Liski et al., 2002; Peltoniemi et al., 2004) and also should be assessed.

The objective of this article is to assess the impact on carbon stocks due to species substitution. We studied the replacement of sessile oak (Quercus petraea Liebl.) high forests issued from natural regeneration by Corsican pine plantations (Pinus nigra subsp. laricio) in central France (Centre and Pays de la Loire regions). Within this area, according to the Inventaire Forestier National (National Forest Inventory, NFI), sessile oak is the main species, and occupies 327000 ha, which represents 
$18 \%$ of the national resource for this species (Belouard, pers. comm.). This substitution is already practiced for production purposes. Corsican pine is appreciated by forest owners for several reasons. It is well adapted even on poor sites and yield can reach up to $20 \mathrm{~m}^{3} / \mathrm{ha} /$ year, with stems of remarkable straightness and good wood quality (Riou Nivert et al., 2001). If proven and substantial, carbon sequestration could be an additional benefit of this species substitution.

This article illustrates the utility of coupling models to address issues for which field measurements cover much too long a time interval to be useful for decision-making needed in the short-term. The study was carried out by coupling models that allowed estimating the changes in carbon of the four compartments for both species (below- and above-ground vegetation, soil organic matter and wood products). We focussed on the carbon stocks and their variations, and did not take into account the effects of energy-consuming building materials and fossil fuel substitution by wood, which would be a valuable continuation of our study. In order to help decision-making at the stand level, we needed to estimate the productivity of both species at the same site, and to consider silvicultural scenarios that are prescribed for either species. Productivity assessment has been carried out by using NFI data to estimate site index in relation to environmental factors and the indicator value of understorey vegetation as did Seynave et al. (2005) for Norway spruce. Silvicultural scenarios were chosen as recommended in guides.

\section{Material and methods}

Model chains were built for both sessile oak and Corsican pine to assess the changes in carbon stocks in the four following compartments: below- and above-ground vegetation, soil organic matter and wood products. Stand biomass is controlled by silviculture and predicted by stand growth models. At each growth cycle, models update the diameter distribution (through tree diameter growth and mortality) and individual heights. All tree and stand characteristics, including carbon stock in biomass, can be computed. Stand dynamics is guided by a dominant height curve (dominant height: mean height of the 100 largest trees per hectare). Site productivity for each species is expressed by site index, which is the dominant height at a reference age (West, 2004). One of the most difficult parts of this work was to assess site index of the alternative species (Corsican pine) knowing the characteristics of 
the previously settled sessile oak stand. The solution to this problem is discussed in the "compared site indices" section. To simplify the study, simulations were carried out under stationary environmental conditions. Therefore, long-term growth changes documented for other species in France (Bontemps et al., 2005) were not taken into account. The differential responses of both species to hazards (windfalls, droughts, fires, insects...) were ignored due to a lack of similar quality response functions. Hence, our results are to be considered as preliminary indications, under stable environmental conditions and without risks.

\section{1 - Compared site indices and site type selection}

The site index definition used in this article for sessile oak even-aged forests is dominant height at the age of 100 years (Duplat and Tran-Ha, 1997). It will be referred as $H_{100}$. As the rotation for Corsican pine is shorter, here site index is the dominant height at the age of 30 years (Lebourgeois et al., 2000) and will be noted $H_{30}$.

The assessment of the site index of both species at the same site was made possible by combining previous studies on Corsican pine productivity in Central France (Gilbert et al., 1996) and NFI data. On one hand, Gilbert et al. (1996) established a determination key to assess $H_{30}$ for Corsican pine, depending on environmental factors and ground vegetation. This determination key splits the geographical area into 35 site types. Among them, the installation of Corsican pine stand is possible for 15 types, but is not recommended for the other ones. The environmental factors needed are available in the NFI data (ground flora composition, soil profile description and annual rainfall). Thus, with this determination key, it is possible to assess the expected value of Corsican pine $H_{30}$ for all plots inventoried by NFI, in particular those occupied by sessile oak high forests. On the other hand, for inventoried sessile oak stands, the NFI measures all tree circumferences and heights in the plot as well as the age of one or two trees by diameter class (small, medium and large trees). Hence, it was possible to select plots only in even-aged forest, to calculate stand age and to estimate dominant height based on the population of the 100 thickest trees per hectare. Finally, stand age and dominant height were used to estimate $H_{100}$ for each sessile oak stand using the growth curve cluster of Duplat and Tran-Ha (1997). 
The selected NFI plots matched the following criteria: i) Geographical area: Cher, Loir-et-Cher, Maine-et-Loire, Mayenne and Sarthe administrative district (south west of Paris), that represents almost $6000 \mathrm{~km}^{2}$ of forested land, ii) sessile oak stands (sessile oak as predominant species), iii) all stands reported as even-aged forests, and, $i v$ ) having data on ground flora composition, soil profile description and annual rainfall. 440 stands corresponded to the above criteria.

The dominant height $\times$ age couples for sessile oak stands are shown on Figure 1. Using the growth curve for sessile oak dominant height given by Duplat and Tran-Ha (1997), the site index $H_{100}$ was calculated. The stand condition, climatic factors and the ground flora composition of all the 440 sessile oak stands were used to assess the relevant site type according to the Gilbert et al. (1996) determination key. Finally, for each site type, we produced an estimation of the mean site index for both Corsican pine and sessile oak (Table 1).

The more relevant site type to study the species substitution was chosen to fulfill the following conditions : (i) installing Corsican pine is possible according to environmental factors (ii) the site productive capacity for Corsican pine is high compared to that for sessile oak stand, and, (iii) there are lot of sessile oak stands that could be replaced by Corsican pine. Given these criteria, the site type chosen for this study is $L 7 a$ (Table 1). This corresponds to a site with a silty soil, without limestone, without strong presence of acidophilous vegetation, and with high precipitation $(>780 \mathrm{~mm} / \mathrm{yr})$ or adequate soil water conditions. The mean site indices for this site type are $H_{30}=15.7 \mathrm{~m}$ for Corsican pine and $H_{100}=24.2 \mathrm{~m}$ for sessile oak.

$2-$ Trees

The vegetation modeled in this study was that of the stand's main species. Understorey and the herbaceous layer were ignored. This simplification is justified by the low carbon content of this compartment in the French forests, estimated at 4\% by Dupouey et al. (1999).

\section{1 - Stand growth simulation}

Sessile oak growth was simulated using the Fagacées growth model (Dhôte and de Hercé, 1994; Dhôte, 1996, 1997), and the PNL model for Corsican pine (Meredieu, 1998). Both models are implemented in the CAPSIS software (version 4.1) (de Coligny et al., 2003). Fagacées and PNL are 
distance independent models designed to simulate thinnings of different intensity and type (low or crown thinnings).

The forest management options chosen for both species corresponded to the silvicultural regimes advised by the Office National des Forêts (ONF, French Forest National Office). For sessile oak, this silvicultural scenario (Jarret, 1996) leads to a 204-year rotation to obtain a dominant diameter of $70 \mathrm{~cm}$. For Corsican pine, two silvicultural scenarios (Riou Nivert, 1996) were simulated. The first one, noted as "intensive", aims at producing good quality wood (without nodes) in a short time (mean diameter $=50 \mathrm{~cm}, 200 \mathrm{stems} / \mathrm{ha}$ ) with 3 prunings when dominant heights are 6,9 and 12 meters. The second one, noted as "structure", aims at producing wood for building structures. The silvicultural objective is to obtain a mean diameter of $40 \mathrm{~cm}$ for $300 \mathrm{stems} / \mathrm{ha}$. Rotation lengths for both Corsican pine silvicultural systems are 64 years (intensive) and 61 years (structure). The number of stems vs. dominant height curves are shown in Figure 2, and the main stand characteristics at the time of final harvest are given in Table 2 .

\section{2 - Carbon calculations}

The carbon content of the ligneous part of the vegetation is assessed using volume equations, basic density at the ring level equations, and the carbon concentration in dry matter.

The volume equations used estimate the total aboveground volume over bark (Vallet et al., 2006). For sessile oak, equation [1] was calibrated with a 1222-trees database, with a $4 \mathrm{~cm}$ to $89 \mathrm{~cm}$ diameter range.

$$
v_{t o t}=\left(\frac{1}{40000 \pi} \cdot c_{130}^{2} \cdot h_{t o t}\right) \times\left(0.471-0.000345 \times c_{130}+0.377 \times \frac{c_{130^{\frac{1}{2}}}}{h_{t o t}}\right)
$$

where $c_{130}$ is circumference in $\mathrm{cm}, h_{t o t}$ total height in $\mathrm{m}$, and $v_{\text {tot }}$ total aboveground volume in $\mathrm{m}^{3}$.

For Corsican pine, Vallet et al. (2006) showed that the same volume equation could be used for pines of different species, even if their diameter and height ranges are different. We checked their pine volume equation (equation [2]), fitted with a 389 Scots pine and 297 maritime pine database, on an independent 77 Corsican pine total volume database (Figure 3a and 3b).

$$
v_{t o t}=\left(\frac{1}{40000 \pi} \cdot c_{130}^{2} \cdot h_{t o t}\right) \times\left(0.311-0.000405 \times c_{130}+0.340 \times \frac{c_{130^{\frac{1}{2}}}}{h_{t o t}}\right) \times\left(1+\frac{191.0}{c_{130}{ }^{2}}\right)
$$


The Fagacées and $P N L$ growth models provide mensurational values of all trees (circumference and height) at each simulation step (3 years for Fagacées, 1 year for $P N L)$. This allows using ringlevel basic density models, applied to the volume of the considered ring. The ring characteristics vary with silviculture. Thus, a ring-level model for basic density is more interesting than a general, speciesspecific coefficient as it allows taking the influence of the silviculture into account. The ring volume was assessed by difference of total aboveground volume estimations (equations [1] and [2]) between two successive steps.

The basic density model for Sessile oak (equation [3] and [4]) is a simplification of a previous work by Le Moguédec (2000), and was fitted with a database of 7483 measurements. For sessile oak, basic density is bounded by 355 and $859 \mathrm{~kg} / \mathrm{m}^{3}$. If the predicted value falls outside the [355 - 859] $\mathrm{kg} / \mathrm{m}^{3}$ interval, the value is fixed at the lower or upper margin. For Corsican pine, basic density equation is given by equation [5]. This model (Leban et al., 1998) is the fixed part of a model with fixed and random variables developed on a database of 13104 measurements.

$$
\begin{aligned}
& b d=574.63-0.676 \times a g e_{c}+\frac{22.61}{r w}(\text { for heartwood }) \\
& b d=533.29-0.676 \times a g e_{c}+\frac{22.61}{r w}(\text { for sapwood }) \\
& b d=352.3+3.42 \times a g e_{c}+92.09 \times \frac{a g e_{c}}{a g e_{t}}-5.27 \times r w
\end{aligned}
$$

where $b d$ is the basic density $\left(\mathrm{kg} / \mathrm{m}^{3}\right), a g e_{c}$ is the cambial age (ring age counted from the pith), $a g e_{t}$ is the age of the tree and $r w$ is the ring width $(\mathrm{mm})$.

Root biomass is often assessed using biomass expansion factors (Schroeder et al., 1997; Dupouey et al., 1999; Lehtonen et al., 2004; Van Camp et al., 2004). We preferred using allometric relations with diameter as the independent variable, in order to avoid compounding errors and to take into account differences between silvicultural scenarios. An allometric relationship for the estimation of sessile oak coarse root biomass was developed by Drexhage et al. (1999). This equation [6] was fitted on 55 sessile oak root systems of trees from 7 to $17 \mathrm{~cm}$ diameter at breast height. No data from larger sessile oak trees where found in literature. Before using this relation in extrapolation for larger trees, we checked with 8 measurements of beech root systems up to $47 \mathrm{~cm}$ diameter at breast height 
(Pellinen, 1986) that the model by Drexhage provided biomass of an appropriate order of magnitude. Of course, this is a rough indication of correctness, rather than a rigorous evaluation, due to the different root system morphologies of these hardwood tree species (taproot for Oak, heart-shaped system for Beech, Köstler et al. 1968).

$$
\log _{10}(\text { biomass })=-1.56+2.44 \times \log _{10}(d b h)
$$

where biomass is dry matter root biomass in $\mathrm{kg}$, and $d b h$ is diameter at breast height in $\mathrm{cm}$.

For Corsican pine, no allometric relation was available to estimate root biomass. Zianis et al. (2005) reviewed many equations to estimate trees or part of trees biomass: seven relations developed for Scots pine roots might have been applied to Corsican pine. Laiho and Finer (1996) developed allometric relations for trees from $4 \mathrm{~cm}$ up to $24 \mathrm{~cm}$ diameter at breast height in Finland, but their model predicted an unreasonable large root biomass for larger trees. Other relations (Santantonio et al., 1977) had been fitted on a too narrow size range to be applied over a whole rotation. The equation by Mälkönen (1974) predicted a biomass much lower than all other ones. Because these results were not convincing, the Drexhage model for Oak was tested. It gave results inside the cluster of Scots pine root biomass curves in the Zianis review (Figure 4). As a consequence, the Drexhage et al. (1999) model [6] was preferred for both species. The consequence of using such a model was checked $a$ posteriori by calculating the time-averaged, stand level root expansion factor (root biomass / aboveground biomass $=0.26$ ). This root expansion factors is close to the value given by Dupouey et al . (1999). Moreover, a sensitivity analysis (see below, in the results and discussion section) showed that the use of the various Zianis review equations instead of the Drexhage equation would not change our main conclusions.

Löwe et al. (2000) reviewed the carbon content of dry matter estimations used by European countries for their national forest carbon reporting. The values range from 0.43 (conifers in Portugal) to 0.519 (pine and spruce in Finland). They are generally the same for different species within a country, and do not differ between conifers and hardwoods. The figure used in this article is 0.475 , corresponding to the value used in Loustau (2004) for the French national carbon reporting.

Leaf carbon is counted using the mean values of dry matter for deciduous species (3.1 tDM/ha) and for coniferous species (7.3 tDM/ha), also taken from Loustau (2004), which were multiplied by 
the carbon content of leaves and needles calculated using the RENECOFOR data (Ulrich et al., 1994). Those percentages are $52.9 \%$ for coniferous and $50.8 \%$ for broadleaved species (Vallet, 2005), and the resulting values are $4.13 \mathrm{tC} / \mathrm{ha}$ for coniferous and $1.57 \mathrm{tC} / \mathrm{ha}$ for broadleaved species.

In the simulation, all the trees are either thinned or harvested, and we did not take into account decaying trees on ground. Deadwood not included in litter is not taken into account either.

\section{3 - Soil carbon}

Soil carbon was estimated using a soil carbon dynamics model and large database to estimate the inputs needed to the soil model. The selected model was Century (Parton et al., 1987; Parton et al., 1994). The database used were obtained from the French part of the European soil monitoring network with a 16x16 km grid (Vanmechelen et al., 1997; Badeau, 1998), and from the RENECOFOR network (Brêthes and Ulrich, 1997; Ponette et al., 1997). Altogether these two networks have 701 plots.

The inputs and parameters needed for the Century model are (i) average climatic data (rainfall, temperature, evapotranspiration), (ii) soil silt + clay fraction, (iii) amount of carbon input (leaves, twigs, root turnover...), and, (iv) lignin / nitrogen ratio of input.

The climatic data were obtained using the Aurelhy model of Météo France (Bénichou and le Breton, 1987). This model gives monthly, normal values of climatic variables at each location of a systematic grid $(1 \mathrm{~km})$. The normal values refer to the 1961 - 1990 period.

The silt + clay fraction had to correspond to the conditions of the study. The value used is the mean value of all soil observations of the systematic $16 \times 16$ network where species is oak and location is within the studied area (Centre and Pays de la Loire regions). This value is 55.5\%.

It is especially difficult to assess the root turnover and the root system decomposition which both are large carbon inputs to the soil. To solve this problem, the Century model was numerically reversed to calculate the carbon inputs for each species (belowground and aboveground together) which lead at steady state to the mean soil carbon value of the 16x16 and RENECOFOR database, using all the values corresponding to the considered species, and calculated from humus layers down to $60 \mathrm{~cm}$ depth. The carbon input values obtained are $3.900 \mathrm{tC} / \mathrm{ha} / \mathrm{yr}$ for sessile oak and $3.456 \mathrm{tC} / \mathrm{ha} / \mathrm{yr}$ for Corsican pine. This method allows the calculation of input values that are reliable for several decades in simulations; however, intra-rotation variations are suppressed. 
The lignin / nitrogen ratio is often given in literature as it is an indicator of decomposition rate. However, decomposition of sessile oak and Corsican pine elements have hardly been studied. The values used in this article are the mean value of all the values found in literature, grouping sessile oak and pedunculate oak together (Table 3 ).

Knowing the parameters and inputs for both species, a first run of the Century model was conducted with sessile oak values until steady state. The resulting values for soil carbon are then used as the initial state for a second run to assess the dynamics of soil carbon after species substitution.

\section{$4-$ Wood products}

The harvested trees are supposed to be used as wood products, except branches and twigs under $7 \mathrm{~cm}$ diameter, which are supposed left on the stand. Wood products were classified in five groups: 1) paper and cardboard, 2) energy wood, 3) construction (building structures, scaffolding, formwork...), 4) furniture, 5) handling (wooden pallets, wooden cases, crates...). The product life cycles of each group were described in Paquet and Deroubaix (2003). The times spent in the first and second industrial processes (from log to board, then from board to final product) as well as in the final utilization are mentioned. The efficiency of these processes for each group are from Selmani (1992) (about $50 \%$ for the first and $80 \%$ for the second, depending on the product group). Analysing the whole product life cycles (Vallet, 2005) allows to calculate the lifespan expectancy of a log assigned to one kind of product, including all losses during the processes, and considering recycling in paper or cardboard or energy use (Table 4). These lifespans are different from the lifespan of a final product. The survival function for the carbon stored in wood products is of the Weibull type (Saporta, 1990), which is often used in material reliability. The Weibull law expectancy corresponds to the lifespan of the wood product group.

It was assumed that the allocation of wood into the five product groups is different between sessile oak and Corsican pine, but that lifespan is the same for both species once a log is assigned to a group.

For sessile oak, the allocation depends of the mean diameter of the log according to the rule of Flammarion (1986) given in Table 5. Then, slicing, cabinet working, fine joinery and ordinary joinery were assigned to furniture, and framework, flooring and sleepers were assigned to construction. To 
take into account the carbon stocks in wood products for sessile oak, a stem taper for this species (Dhôte et al., 2000) was used on each harvested tree. Stem taper allows making logs 2 meters long with each harvested tree and to assess their mean diameters in order to divide them following the rule of Flammarion described above.

For Corsican pine, the allocation of harvested trees between different products (Meredieu et al., 1999) was done using the WinEpiFn software (Houllier et al., 1995). This software allows assessing the logs and then cutting them into boards (dimensions and quality) that could be obtained from a Corsican pine tree knowing its characteristics (stem taper, branch characteristics). These boards are then assigned to the five different product groups according to the wood uses for this species reported in (CTBA, 1994; ARBOCENTRE, 2005). The uses of Corsican pine wood are joinery, construction and handling with the percentages described in Table 6.

\section{Results and discussion}

The impact of species substitution on carbon stocks in the abovementioned conditions can be analysed for the steady state and transient state. The steady state is obtained when the same silviculture is repeated many times. The transient state is the dynamic that will occur after species substitution and that will lead to the steady state. We recall that for these two types of simulations the environmental conditions were regarded as stable.

\section{1 - Steady state}

For the steady state analysis, the more relevant figure to make a species comparison is the timeaveraged carbon stock for all the compartments over the whole rotation (Figure 5). The average carbon stock was estimated at $221 \mathrm{tC} /$ ha for sessile oak and $179 \mathrm{tC} / \mathrm{ha}$ or $174 \mathrm{tC} / \mathrm{ha}$ for Corsican pine with intensive or structure scenarios. The amount of soil carbon was almost the same in the three cases: 93tC/ha. Litter production was higher for sessile oak than for Corsican pine (3.900 tC/ha/yr and 3.456 $\mathrm{tC} / \mathrm{ha} / \mathrm{yr}$ ). However, the lignin / nitrogen ratio was higher for Corsican pine (Table 3). Litter production and lignin / nitrogen ratio effects compensate, leading to the same value of soil carbon. It represents $42 \%$ of total carbon in sessile oak, $52 \%$ and $53 \%$ in Corsican pine. One would think that under a pine system, with higher growth rates and less decomposable needle, carbon stocks in soils 
would be higher. However, the database we used to calculate these stocks contain 172 oak sites and 135 pine sites, which give confidence in the result. If soil carbon stocks are usually higher under pines or spruces or firs than under oaks, it could also be partially due other factors, such as climate or pedologic conditions. As we considered species substitution on the same site, the other factors are kept the same here. Moreover, soil carbon variability is very high, and we can find opposite results in literature. For example, Nabuurs and Schelhass (2002) compared 16 forests systems across Europe, and had four pine systems (Scots pine and Maritime pine) and one sessile oak system. The soil carbon content under oak was higher than all the four pine systems.

The percentage of carbon in wood products was low: $5 \%$ in sessile oak, $8.5 \%$ and $8 \%$ in Corsican pine. The higher percentage in Corsican pine is due to a shorter rotation, and to a higher proportion of construction wood. The total carbon stock differences between both species are mainly in the aerial and root biomass (117 tC/ha for sessile oak vs. $71 \mathrm{tC} / \mathrm{ha}$ and $67 \mathrm{tC} /$ ha for Corsican pine).

The replacement of sessile oak even-aged forest by Corsican pine plantation would lead to a 42 $\mathrm{tC} / \mathrm{ha}$ to $47 \mathrm{tC} / \mathrm{ha}$ lower mean carbon stock at steady state depending on the silvicultural hypothesis for Corsican pine (figure 5).

\section{2 - Transient state}

The dynamics of carbon stock for both Corsican pine silvicultural regimes were similar to each other. As a consequence, only the results for the intensive silviculture are shown for transient state analysis (Figure 6). The Corsican pine rotation is about three times shorter than the sessile oak one (64 years vs. 204 years). Yet, the productivity of Corsican pine is higher than that of sessile oak. This leads to a same maximum value of carbon stock at the end of rotation for both species (about 290 $\mathrm{tC} / \mathrm{ha})$

After the first rotation of Corsican pine, the short time the carbon is stored in wood products implies that carbon rapidly returns to the atmosphere and the total carbon stock falls down to about $110 \mathrm{tC} / \mathrm{ha}, 80$ years after the species substitution. The changes in carbon stock in the case of sessile oak is marked by a longer rotation, slower dynamics and a much longer proportion of time spent at adult stages with high levels of carbon stock. These differences in stand management explain the ranking of the time-averaged mean stocks exposed beforehand. 
Thus, at the end of the first rotation of the Corsican pine, its carbon stock is $102 \mathrm{tC} / \mathrm{ha}$ higher than in the case of sessile oak, which corresponds to a mean additional uptake of $1.6 \mathrm{tC} / \mathrm{ha} / \mathrm{yr}$ during 64 years.

Pine plantation forestry in France benefits from progress in silviculture and genetic improvement, in particular for Maritime pine in the Landes region. The highly appreciated Corsican pine could follow the same trend. The likely impact for this study would be a shorter rotation length, which would still accentuate the difference between sessile oak and Corsican pine at the end of the first rotation, but should not change the result obtained for the steady state.

\section{3 - Reliability of the carbon estimations}

The method used in this article was to combine different equations to create model chains, one for sessile oak and one for Corsican pine, to estimate the dynamics of carbon stocks. Both $P N L$ and Fagacées growth models have been validated in previous works with independent data. $P N L$ was validated in a work of Belingard et al. (2002), and Fagacées was validated in a work of Nepveu and Dhôte (1998) for various silvicultural conditions.

The sessile oak volume equation was fitted to a large data set (1222 trees) containing a wide range of diameters and heights ; the quality of predictions was evaluated for national-scale carbon reporting in (Vallet et al., 2006). For pine, the volume equation used was fitted to 389 Scots pine and 297 maritime pine, and we checked that this equation was also well adapted for Corsican pine (Figure $3 a$ and $3 b)$. The double entry type (circumference and height), as well as the presence of a variable

representing tree hardiness (variable $c_{130}{ }^{0.5} / h_{\text {tot }}$ ) in both volume equations [1] and [2], give a good robustness to the method for addressing various silvicultural conditions. For volume as for basic density models, the fitting material were large databases covering the region under study. However, the recent reviews of Zianis et al. (2005) and the addendum of Muukkonen and Mäkipää (2006), compiling 607 biomass equations and 230 volume equations from the literature, illustrate the lack of information concerning sessile oak and Corsican pine. A more in-depth evaluation of our procedure would be interesting, for example using stand-level volume measurements by laser-scanning.

The root compartment is certainly the less reliable part of our study. For root biomass, the comparison of the Drexhage et al. model (1999) to Pellinen data (1986) and to the models given in the 
Zianis et al. review (2005) for Scots pine (Figure 4) shows that the Drexhage equation is within the range of existing references. Nevertheless, accuracy remains questionable. We performed a sensitivity analysis to assess the impact of using the Drexhage model instead of alternative Scots pine equations from the Zianis review (table 7). We found out that the belowground/aboveground biomass ratio derived from the Drexhage model is close to the commonly accepted values for conifers (Dupouey et al., 1999), whereas the extreme ratios obtained for alternative models are not. Furthermore, even with models exhibiting extreme behaviours, the mean total carbon stock would be respectively $187 \mathrm{tC} / \mathrm{ha}$ and $169 \mathrm{tC} / \mathrm{ha}$ : this would not change our conclusion on the ranking of sessile oak and Corsican pine.

For soil carbon, the method we used is constrained, by construction, to provide stock values close to the observed values in European soil monitoring networks. However, we estimated the carbon input to the soil by reversing model Century: provided that the model parameters are correct, this procedure is valid only if soil carbon is in equilibrium with vegetation. This hypothesis probably holds for oak on State Forests, since land use changes were very limited here over centuries. On private lands and/or in Corsican pine plantations, the equilibrium conditions may not be verified. However, testing the impact of these restrictions was far beyond our possibilities, and this contributes to an uncertainty that is common to soil carbon studies (see review from Yanai et al., 2003). Direct measurements of carbon inputs to the soil would be very valuable, particularly to test the compensation between carbon inputs and lignin/nitrogen ratios for the compared species.

The estimation of carbon in wood products is based upon life cycle analysis and on estimated lifespans of final products. Several parameters are poorly known, e.g. the proportion of final products that are recycled or the lifespans of products. However, the relative contribution of products to the whole carbon stock is small (5 to $8 \%$ ). This implies that the inaccuracy on products has little influence on the main result. As an example, if two years were added to all wood products lifespans, which implies a $100 \%$ increase for the life spans of energy wood, $22 \%$ for construction wood and $24 \%$ for furniture (Table 4), the part of carbon stored in wood products at steady state would increase from 11 $\mathrm{tC} / \mathrm{ha}$ to $14.4 \mathrm{tC} / \mathrm{ha}$, and the contribution of products to the total stored carbon would increase from 5 to $6.4 \%$. This increase is negligible compared to the $42 \mathrm{tC} /$ ha to $47 \mathrm{tC} / \mathrm{ha}$ difference between the timeaveraged carbon stock of Corsican pine and sessile oak. 


\section{4 - Why is there such a small time-averaged proportion of carbon in wood products?}

The proportion of carbon in wood products at steady state is only $5 \%$ for sessile oak and $8 \%$ and 8.5\% depending on silviculture for Corsican pine. This proportion seems small, but is in accordance with other work in literature: Liski et al. (2001) studied the most favourable rotation length for carbon storage for Scots pine in Finland. Their time-averaged carbon stock estimation in vegetation is 38 $\mathrm{tC} / \mathrm{ha}$ and $7.4 \mathrm{tC} / \mathrm{ha}$ in wood products. Our figures for a Corsican pine intensive silviculture are 71 $\mathrm{tC} / \mathrm{ha}$ in biomass and $15 \mathrm{tC} / \mathrm{ha}$ in wood products. The higher values for Corsican are probably due to stand productivity and rotation length differences. The ratio between stocks in product and vegetation is $19.4 \%$ in Liski et al. (2001), $21 \%$ in our simulations.

This small contribution of wood products is due to three factors. First, wood losses during wood processing depends on the kind of products, and is generally about $50 \%$ during the first process (from $\log$ to board) and between $20 \%$ and $30 \%$ during the second process (from board to final product) (Selmani, 1992). Hence, only $35 \%$ to $40 \%$ of the harvested volume will become final products. Losses will become products of shorter life spans (energy, paper wood...). Secondly, all the products do not have long lifespans. For example, wood in building structures has a long life span (40 years), but represents only $23 \%$ of the construction final products. Moreover, construction final products are the product with the longest lifespan. Energy and paper wood have only a 2 years lifespan, and represent a large amount of harvested wood. Third, product lifespans are compared to rotation lengths that are much longer: 61 and 64 years for Corsican pine stands, and 204 years for sessile oak stands. One of the hypotheses for wood product is that all the wood is used for final products and recycled, or for energy; wood that could decay in landfills is not evaluated and could slightly increase the proportion of this compartment.

\section{Conclusion}

The substitution of a slow-growing sessile oak even-aged forest by a fast-growing Corsican pine plantation would have effects on carbon storage depending on the time considered. As Cannell (1996) assumed in a previous work, we show here that during the first rotation, the Corsican pine plantation 
would have a higher carbon uptake, but that the time-averaged carbon stocks would be lower at steady state, in comparison with slow-growing oak stands spending decades at adult stages.

The additional carbon storage of the Corsican pine plantation with the intensive silviculture compared to sessile oak could be $102 \mathrm{tC} / \mathrm{ha}$ after 64 years (Figure 6), which implies an additional storage of about $1.6 \mathrm{tC} / \mathrm{ha} / \mathrm{yr}$ during 64 years. However, after the first rotation, harvesting of the plantation would imply a high and rapid return of carbon to the atmosphere. At steady state, the time averaged carbon stock is $42 \mathrm{tC} / \mathrm{ha}$ to $47 \mathrm{tC} /$ ha lower for the Corsican pine plantation. These results were obtained by simulating forest management guidelines advised by the National Forest Office, in a situation favourable for species substitution (site type with a high productivity for Corsican pine and moderate productivity for sessile oak).

Further studies could improve and complement our results. First, new data on belowground compartments (root systems and soil carbon dynamics) would provide accuracy on the estimations. Second, carbon stocks variations in all the forests ecosystems compartments are accounted for, but the difference of wood harvesting and process between species could imply differences in carbon energy use, as well as differences of fossil fuel savings by energy or construction wood. Even if this is probably not enough to reverse conclusions, this might modify the results. Other changes, such as socio-economics, biodiversity or level of risks modifications could arise if this substitution was applied and could be studied as well. Finally, productivity changes in the last century were reported (Spiecker et al., 1996; Bontemps et al., 2005). Similar studies could be conducted with projections for the next century.

Beyond the results given in the particular case of substituting sessile oak by Corsican pine, this study shows the contribution that assembling models could bring to address complex systems evolution issues. Other carbon balance systems such as CO2FIX (Masera et al., 2003) or GORCAM (Marland and Schlamadinger, 1997) exist and can provide information on changing carbon stocks with species substitutions. The type of tools constructed in those studies is needed to provide scientific data for forest managers and policymakers. 


\section{Acknowledgements}

The authors wish to thank Christian Piedallu (ENGREF) for the work done on the GIS to get the climatic data, Vincent Badeau (INRA) for providing data from the European soil monitoring network, Marc Lanier and Erwin Ulrich from RENECOFOR for providing soil data, and Gilles Le Moguédec (INRA) for the basic density equation for sessile oak. The work was done during a $\mathrm{PhD}$ thesis with scholarships from ADEME and the Conseil Regional de Lorraine. 


\section{References}

ARBOCENTRE, 2005. L'utilisation du Pin en région Centre, Pin durable Volet 2. Rapport interne, 39 p.

Badeau, V., 1998. Caractérisation écologique du Réseau européen de suivi des dommages forestiers Bilan des opérations de terrain et premiers résultats, Les Cahiers du DSF 5-1998, 211 p.

Belingard, C., Vinson, J., Perret, S., 2002. Modélisation du Pin laricio. Validation - transfert. Rapport de convention DERF/Cemagref $\mathrm{n}^{\circ} 61.45 .24 / 00,50 \mathrm{p}$.

Bénichou, P., le Breton, O., 1987. Prise en compte de la topographie pour la cartographie de champs pluviométriques statistiques: la méthode Aurelhy. Colloques de l'INRA No. 39, 51-69.

Bontemps, J.-D., Vallet, P., Herve, J.-C., Rittié, D., Dupouey, J.-L., Dhôte, J.-F., 2005. Des hêtraies qui poussent de plus en plus vite : vers une forte diminution de leur âge d'exploitabilité ? Revue Forestière Française LVII, $n^{\circ}$ spécial 2 : L'avenir du Hêtre dans la forêt française, 123 142.

Brêthes, A., Ulrich, E., 1997. RENECOFOR - Caractéristiques pédologiques des 102 peuplements du réseau, Office National des Forêts, Département des Recherches Techniques, Fontainebleau, $575 \mathrm{p}$.

Cannell, M., 1995. Forests and the global carbon cycle in the past, present and future. Research Report $\mathrm{n}^{\circ} 2$ - European Forest Institute, $66 \mathrm{p}$.

Cannell, M., 1996. Forests as carbon sinks mitigating the greenhouse effect. Commonwealth Forestry Review 75, 92-99.

Cortez, J., Demard, J.M., Bottner, P., Monrozier, L.J., 1996. Decomposition of mediterranean leaf litters: a microcosm experiment investigating relationships between decomposition rates and litter quality. Soil Biology \& Biochemistry 28, 443-452.

Cropper, W.P., Jr., Ewel, K.C., 1987. A regional carbon storage simulation for large-scale biomass plantations. Ecological Modelling 36, 171-180.

CTBA, 1994. Les résineux Français. Plaquette réalisée avec le concours financier de l'ADEME et Formabois, avec la collaboration de la FNB.

de Coligny, F., Ancelin, P., Cornu, G., Courbaud, B., Dreyfus, P., Goreaud, F., Gourlet-Fleury, S., Meredieu, C., Saint-Andre, L., 2003. CAPSIS: computer-aided projection for strategies in silviculture: advantages of a shared forest-modelling platform. In, Modelling forest systems. Workshop on the interface between reality, modelling and the parameter estimation processes, Sesimbra, Portugal, 2-5 June 2002, pp. 319-323.

de Santo, A.V., Rutigliano, F.A., Berg, B., Fioretto, A., Puppi, G., Alfani, A., 2002. Fungal mycelium and decomposition of needle litter in three contrasting coniferous forests. Acta Oecologica 23, 247-259. 
Dewar, R.C., Cannell, M., 1992. Carbon sequestration in the trees, products and soils of forest plantations: an analysis using UK examples. Tree Physiology 11, 49-71.

Dhôte, J.-F., 1996. A model of even-aged beech stands productivity with process-based interpretations. Annales des Sciences Forestières 53, 1-20.

Dhôte, J.-F., 1997. Effets des éclaircies sur le diamètre dominant dans des futaies régulières de Hêtre ou de Chêne sessile. Revue Forestière Française 49, 557-578.

Dhôte, J.-F., de Hercé, E., 1994. Un modèle hyperbolique pour l'ajustement de faisceaux de courbes hauteur-diamètre. Canadian Journal of Forest Research 24, 1782-1790.

Dhôte, J.-F., Hatsch, E., Rittié, D., 2000. Forme de la tige, tarifs de cubage et ventilation de la production en volume chez le Chêne sessile. Annals of Forest Science 57, 121-142.

Drexhage, M., Chauviere, M., Colin, F., Nielsen, C.N.N., 1999. Development of structural root architecture and allometry of Quercus petraea. Canadian Journal of Forest Research 29, 600608.

Duplat, P., Tran-Ha, M., 1997. Modélisation de la croissance en hauteur dominante du Chêne sessile (Quercus petraea Liebl.) en France. Variabilité inter-régionale et effet de la période récente (1959-1993). Annals of Forest Science 54, 611-634.

Dupouey, J.L., Pignard, G., Badeau, V., Thimonier, A., Dhote, J.F., Nepveu, G., Berges, L., Augusto, L., Belkacem, S., Nys, C., 1999. Stocks et flux de carbone dans les forêts françaises. Comptes Rendus de l'Académie d'Agriculture de France 85, 293-310.

Erb, K.H., 2004. Land use-related changes in aboveground carbon stocks of Austria's terrestrial ecosystems. Ecosystems 7, 563-572.

Fioretto, A., Musacchio, A., Andolfi, G., Santo, A.V.d., 1998. Decomposition dynamics of litters of various pine species in a Corsican pine forest. Soil Biology \& Biochemistry 30, 721-727.

Flammarion, J.-P., 1986. Regroupement en lots par classes de diamètre, Rapport interne. Laboratoire d'Economie Forestière, Engref, Nancy.

Fleming, T.L., Freedman, B., 1998. Conversion of natural, mixed-species forests to conifer plantations: implications for dead organic matter and carbon storage. Ecoscience 5, 213-221.

Gilbert, J.M., Chevalier, R., Dumas, Y., 1996. Autécologie du pin laricio de Corse dans le secteur ligérien. Revue Forestière Française 48, 201-216.

Harmon, M.E., Ferrell, W.K., Franklin, J.F., 1990. Effects on carbon storage of conversion of oldgrowth forests to young forests. Science (Washington) 247, 699-702.

Houllier, F., Leban, J., Colin, F., 1995. Linking growth modelling to timber quality assessment for Norway spruce. Forest Ecology and Management 74, 91-102.

Jarret, P., 1996. Sylviculture du Chêne sessile. Bulletin Technique - Office National des Forets 31, 2128.

Karjalainen, T., Kellomaki, S., Pussinen, A., 1994. Role of wood-based products in absorbing atmospheric carbon. Silva Fennica 28, 67-80. 
Karjalainen, T., Pussinen, A., Liski, J., Nabuurs, G.J., Erhard, M., Eggers, T., Sonntag, M., Mohren, G.M.J., 2002. An approach towards an estimate of the impact of forest management and climate change on the European forest sector carbon budget: Germany as a case study. Forest Ecology and Management 162, 87-103.

Köstler, J.N., Brückner, E., Bibelriether, E., 1968. Die Wurzeln des Waldbäume, Verlag Paul Parey, Hamburg, Germany, 284 p.

Laiho, R., Finer, L., 1996. Changes in root biomass after water-level drawdown on pine mires in southern Finland. Scandinavian Journal of Forest Research 11, 251-260.

Le Moguédec, G., 2000. Modélisation de propriétés de base du bois (coefficients de gonflement et densité du bois) et de leur variabilité chez le Chêne sessile (Quercus petraea Liebl.). Simulations en vue de l'évaluation d'une ressource forestière, PhD Thesis, INA-PG, Paris, 290 p.

Leban, J.-M., Riou-Nivert, P., Grandemange, F., Myrlyas, W., Gilbert, J.M., Chevalier, R., 1998. Influence de l'âge et de la vitesse de croissance sur la qualité du bois de Pin laricio. Rapport final de la convention $\mathrm{N}^{\circ} 96.05$ financée par le conseil régional Centre (via ARBOCENTRE). Document interne de l'ERQB, Champenoux, France, 40 p.

Lebourgeois, F., Becker, M., Chevalier, R., Dupouey, J.L., Gilbert, J.M., 2000. Height and radial growth trends of Corsican pine in western France. Canadian Journal of Forest Research 30, 712-724.

Lehtonen, A., Makipaa, R., Heikkinen, J., Sievanen, R., Liski, J., 2004. Biomass expansion factors (BEFs) for Scots pine, Norway spruce and birch according to stand age for boreal forests. Forest Ecology and Management 188, 211-224.

Lindner, M., 1998. Implementing carbon mitigation measures in the forestry sector - a review. In: Kohlmaier, G.H., Weber, M., Houghton, R.A. (Eds.), Carbon dioxide mitigation in forestry and wood industry: papers based on an international workshop. Springer-Verlag, Berlin Germany, pp. 167-184.

Liski, J., Perruchoud, D., Karjalainen, T., 2002. Increasing carbon stocks in the forest soils of western Europe. Forest Ecology and Management 169, 159-175.

Liski, J., Pussinen, A., Pingoud, K., Makipaa, R., Karjalainen, T., 2001. Which rotation length is favourable to carbon sequestration? Canadian Journal of Forest Research 31, 2004-2013.

Loustau, D., 2004. Séquestration de carbone dans les grands écosystèmes forestiers en France. Quantification, spatialisation, vulnérabilité et impacts de différents scénarios climatiques et sylvicoles, Rapport Final Projet GICC 2001 "Gestion des impacts du changement climatique" et convention Gip ECOFOR n³/2001, juin 2004, Inra, Bordeaux-Pierroton (France), 137 p.

Löwe, H., Seufert, G., Raes, F., 2000. Comparison of methods used within Member States for estimating CO2 emissions and sinks according to UNFCCC and EU Monitoring Mechanism: forest and other wooded land. Biotechnologie, Agronomie, Société et Environnement 4, 315 319.

Mälkönen, E., 1974. Annual primary production and nutrient cycle in some Scots Pine stands. Communicationes Instituti Forestalis Fenniae 84, 1-87. 
Marland, E., Marland, G., 2003. The treatment of long-lived, carbon-containing products in inventories of carbon dioxide emissions to the atmosphere. Environmental Science and Policy $6,139-152$.

Marland, G., Schlamadinger, B., 1997. Forests for carbon sequestration or fossil fuel substitution? A sensitivity analysis. Biomass and Bioenergy 13, 389-397.

Masera, O.R., Garza-Caligaris, J.F., Kanninen, M., Karjalainen, T., Liski, J., Nabuurs, G.J., Pussinen, A., de Jong, B.H.J., Mohren, G.M.J., 2003. Modeling carbon sequestration in afforestation, agroforestry and forest management projects: the CO2FIX V.2 approach. Ecological Modelling 164, 177-199.

Meredieu, C., 1998. Croissance et branchaison du Pin laricio (Pinus nigra Arnold ssp. laricio (Poiret) Maire): Élaboration et évaluation d'un système de modèles pour la prévision de caractéristiques des arbres et du bois, PhD Thesis, Univ. Cl. Bernard Lyon I, 250 p.

Meredieu, C., Dreyfus, P., Saint-André, L., Leban, J.-M., 1999. A chain of models from tree growth to properties of boards for Pinus nigra ssp. laricio Arn. : simulation using CAPSIS CINRA and WinEpifn CINRA. In IUFRO workshop S5.01-04 "Connection between silviculture and wood quality through modelling approaches and simulation software", La Londe-les-Maures (France), September 1999, G. Nepveu (ed.) ERQB-INRA 1999/2, 505-513.

Muukkonen, P., Mäkipää, R., 2006. Biomass equations for European trees: Addendum. Silva Fennica 40, 763-773.

Nabuurs, G.J., Schelhaas, M.J., 2002. Carbon profiles of typical forest types across Europe assessed with CO2FIX. Ecol. Indic. 1, 213-223.

Nepveu, G., Dhôte, J.-F., 1998. Sylviculture et qualité du bois de Chêne sessile, Rapport Final de la Convention INRA-ONF 1992-1996 "Sylviculture et Qualité du Bois de Chêne", INRA, Champenoux, France, 68 p.

Paquet, P., Deroubaix, G., 2003. Extension de l'éligibilité de la séquestration forestière du carbone à l'ensemble des stocks de la filière bois. Coordination CTBA. Rapport à l'ADEME pour le Programme GICC, 148p.

Parton, W.J., Schimel, D.S., Cole, C.V., Ojima, D.S., 1987. Analysis of factors controlling soil organic matter levels in Great Plains grasslands. Soil Science Society of America Journal 51, 1173 1179 .

Parton, W.J., Schimel, D.S., Ojima, D.S., Cole, C.V., 1994. A general model for soil organic matter dynamics: sensitivity to litter chemistry, texture and management. In, Quantitative modeling of soil forming processes: proceedings of a symposium sponsored by Divisions S-5 and S-9 of the Soil Science Society of America in Minneapolis, Minnesota, USA, 2 Nov. 1992. Soil Science Society of America Inc., Madison USA, pp. 147-167.

Pellinen, P., 1986. Biomasseuntersuchungen im Kalkbuchenwald, PhD Thesis, Universität, Göttingen, Germany, 134 p.

Peltoniemi, M., Makipaa, R., Liski, J., Tamminen, P., 2004. Changes in soil carbon with stand age - an evaluation of a modelling method with empirical data. Global Change Biology 10, 2078-2091.

Ponette, Q., Ulrich, E., Brêthes, A., Bonneau, M., Lanier, M., 1997. RENECOFOR - Chimie des sols dans les 102 peuplements du réseau, Office National des Forêts, Département des Recherches Techniques, Fontainebleau, 427 p. 
Riou Nivert, P., 1996. Sylviculture du pin laricio en reboisement. Bulletin Technique - Office National des Forets 31, 53-58.

Riou Nivert, P., Meredieu, C., Dreyfus, P., Leban, J.-M., Grandemange, F., Matz, S., Daquitaine, R., Mothe, F., Saint-André, L., Caraglio, Y., 2001. Dossier: le pin laricio, du plant a la planche. Forêt-Entreprise 137, 17-48.

Santantonio, D., Hermann, R.K., Overton, W.S., 1977. Root biomass studies in forest ecosystems. Pedobiologia 17, 1-31.

Saporta, G., 1990. Probabilités, analyse des données et statistique. Technip, Paris, 493 p.

Sariyildiz, T., Anderson, J.M., 2003. Decomposition of sun and shade leaves from three deciduous tree species, as affected by their chemical composition. Biology and Fertility of Soils 37, 137-146.

Schroeder, P., Brown, S., Mo, J., Birdsey, R., Cieszewski, C., 1997. Biomass estimation for temperate broadleaf forests of the United States using inventory data. Forest Science 43, 424-434.

Schroth, G., D'Angelo, S.A., Teixeira, W.G., Haag, D., Lieberei, R., 2002. Conversion of secondary forest into agroforestry and monoculture plantations in Amazonia: consequences for biomass, litter and soil carbon stocks after 7 years. Forest Ecology and Management 163, 131-150.

Selmani, Y., 1992. Analyse des flux physiques de bois à l'intérieur de la filière bois, $\mathrm{PhD}$ Thesis, Engref, Nancy, $241 \mathrm{p}$.

Seynave, I., Gégout, J.C., Hervé, J.C., Dhôte, J.F., Drapier, J., Bruno, E., Dumé, G., 2005. Picea abies site index prediction by environmental factors and understorey vegetation: a two-scale approach based on survey databases. Canadian Journal of Forest Research 35, 1669-1678.

Spiecker, H., Mielikäinen, M., Köhl, M., Skovsgaard, J.P., 1996. Growth trends in European forests. Springer-Verlag, Berlin, Heidelberg, 367 p.

Ulrich, E., Lanier, M., Roullet, P., 1994. RENECOFOR - Manuel de référence ${ }^{\circ} 5$ pour la collecte de la litière et le traitement des échantillons recueillis, placette de niveau 1, Office National des Forêts, Département des Recherches Techniques, Fontainebleau.

Vallet, P., 2005. Impact de différentes stratégies sylvicoles sur la fonction "puits de carbone" des peuplements forestiers. Modélisation et simulation à l'échelle de la parcelle, $\mathrm{PhD}$ Thesis, Engref, Nancy, 195 p.

Vallet, P., Dhôte, J.-F., Le Moguédec, G., Ravart, M., Pignard, G., 2006. Development of total aboveground volume equations for seven important forest tree species in France. Forest Ecology and Management 229, 98-110.

Van Camp, N., Vande Walle, I., Mertens, J., De Neve, S., Samson, R., Lust, N., Lemeur, R., Boeckx, P., Lootens, P., Beheydt, D., Mestdagh, I., Sleutel, S., Verbeeck, H., Van Cleemput, O., Hofman, G., Carlier, L., 2004. Inventory-based carbon stock of Flemish forests: a comparison of European biomass expansion factors. Annals of Forest Science 61, 677-682.

Vanmechelen, L., Groenemans, R., Van Ranst, E., 1997. Forest soil condition in Europe. Result of a large-scale soil survey. EC-UN/ECE, Ministry of the Flemish Community, Brussels, Geneva, $198 \mathrm{p}$.

West, P.W., 2004. Tree and forest measurement. Springer-Verlag, 167 p. 
Yanai, R.D., Currie, W.S., Goodale, C.L., 2003. Soil carbon dynamics after forest harvest: an ecosystem paradigm reconsidered. Ecosystems 6, 197-212.

Zianis, D., Muukkonen, P., Mäkipää, R., Mencuccini, M., 2005. Biomass and Stem Volume Equations for Tree Species in Europe, Silva Fennica - Monographs, 63 p. 


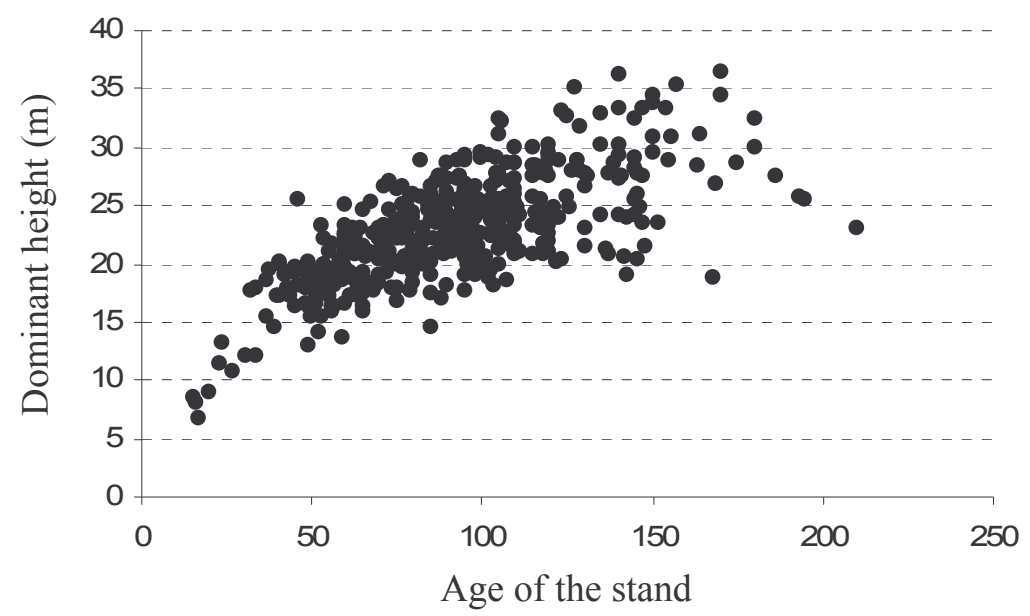

Figure 1: Dominant height vs. age of the stand for the 440 sessile oak stands selected in NFI data 


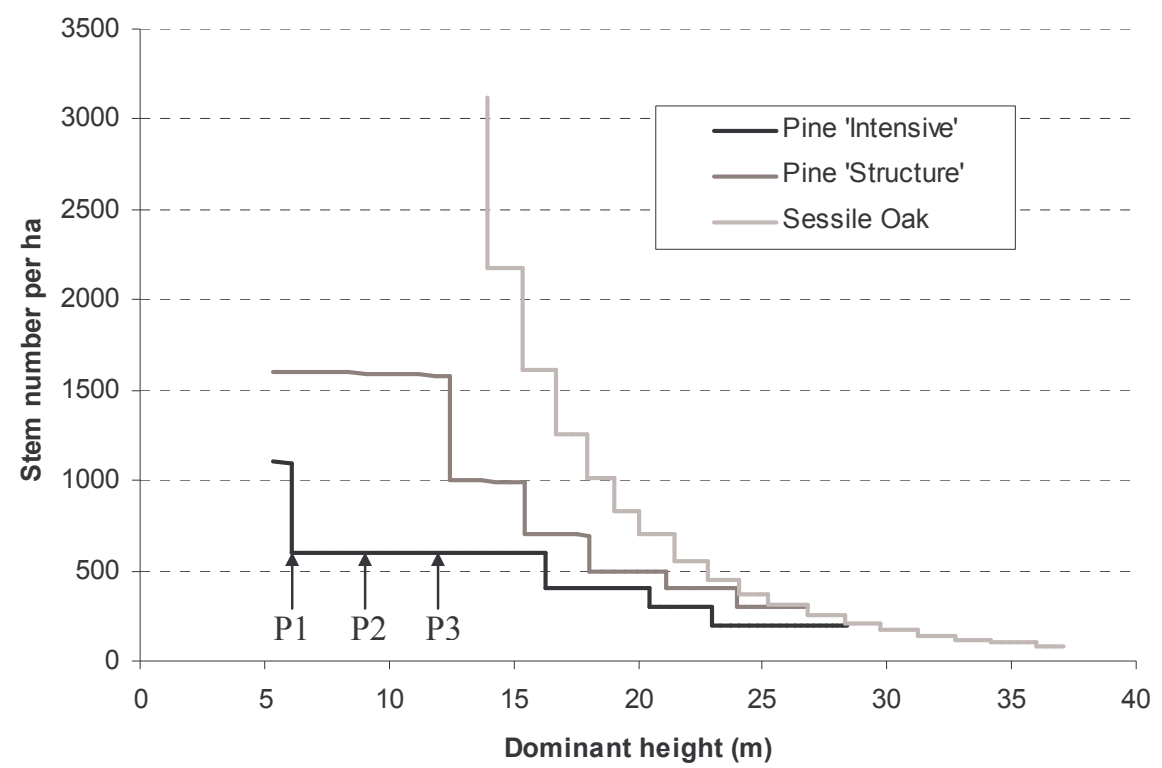

Figure 2: Number of stems vs. dominant height for the sessile oak and pine silviculture $\mathrm{P} 1$ : pruning when dominant height is $6 \mathrm{~m}$, of $2.5 \mathrm{~m}$, on 400 stems P2: pruning when dominant height is $9 \mathrm{~m}$, of $4 \mathrm{~m}$, on 300 stems P3: pruning when dominant height is $12 \mathrm{~m}$, of $6 \mathrm{~m}$, on 200 stems 


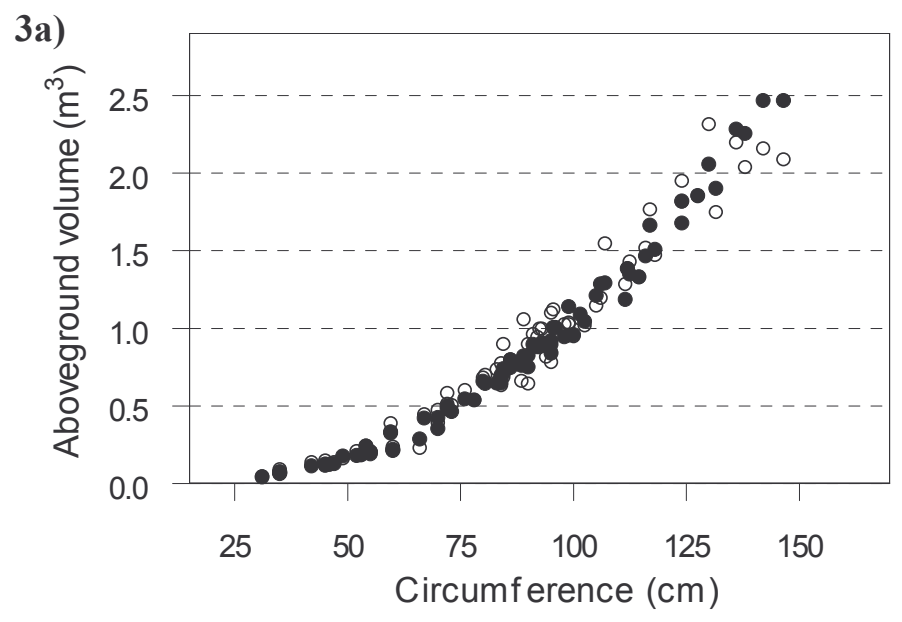

Figure 3a: Total aboveground volume vs. circumference for 77 Corsican pines Empty circles are measured volumes, solid circles are estimated volumes

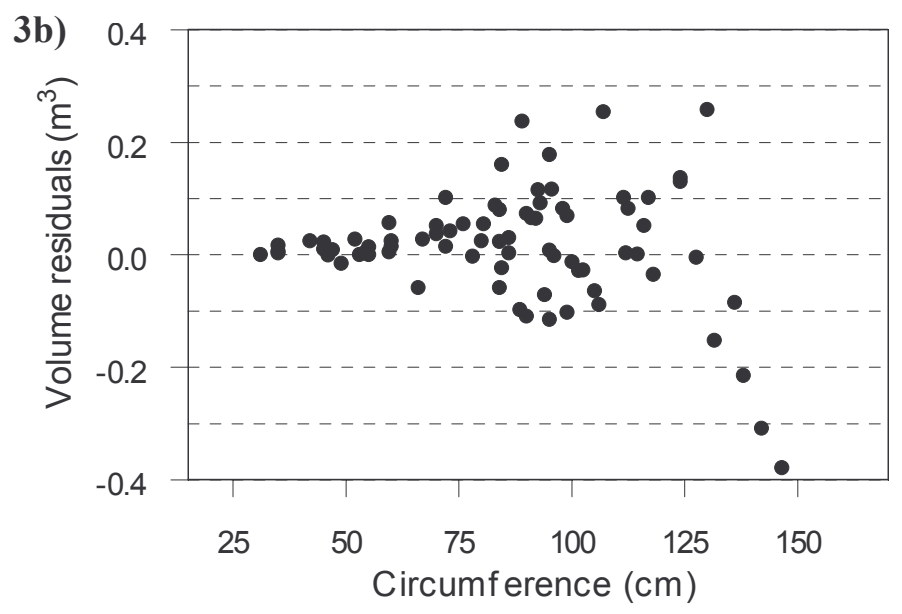

Figure 3b: Total aboveground volume residuals for the 77 Corsican pines 




Figure 4: Drexhage model (1999) for root biomass (bold line) and models given in the Zianis review (2005) for Scots pine root biomass (thin lines) 


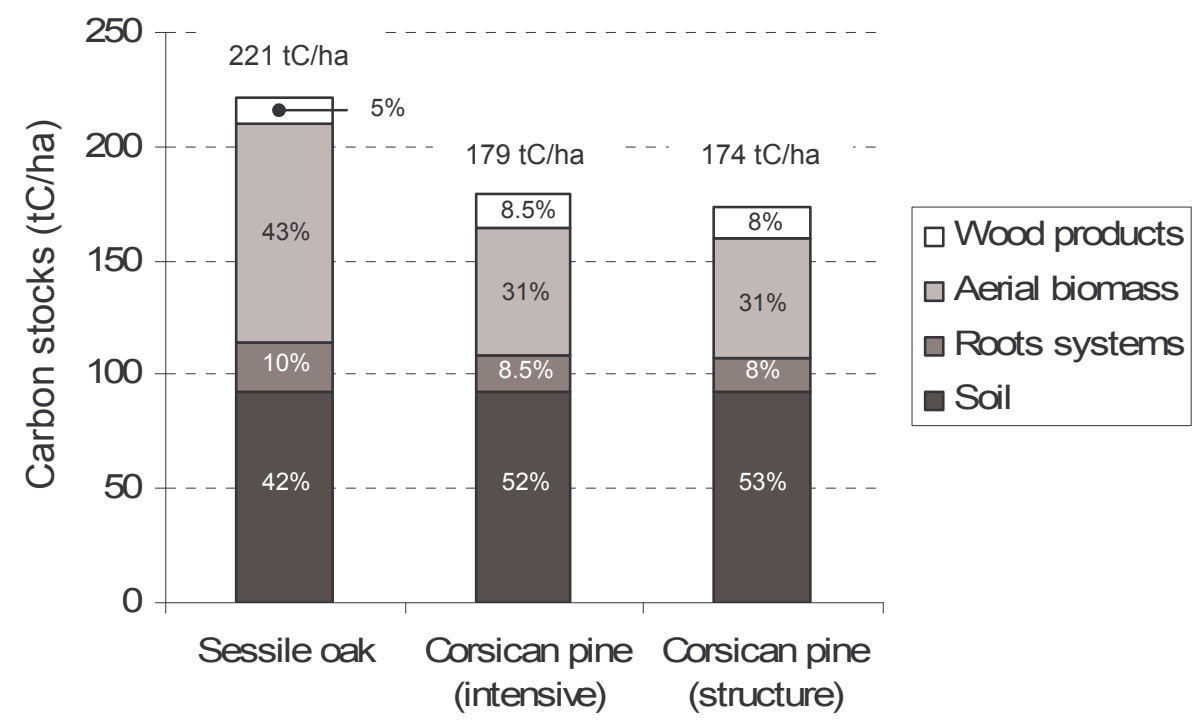

Figure 5: Time-averaged carbon stocks for the 3 silviculture types 


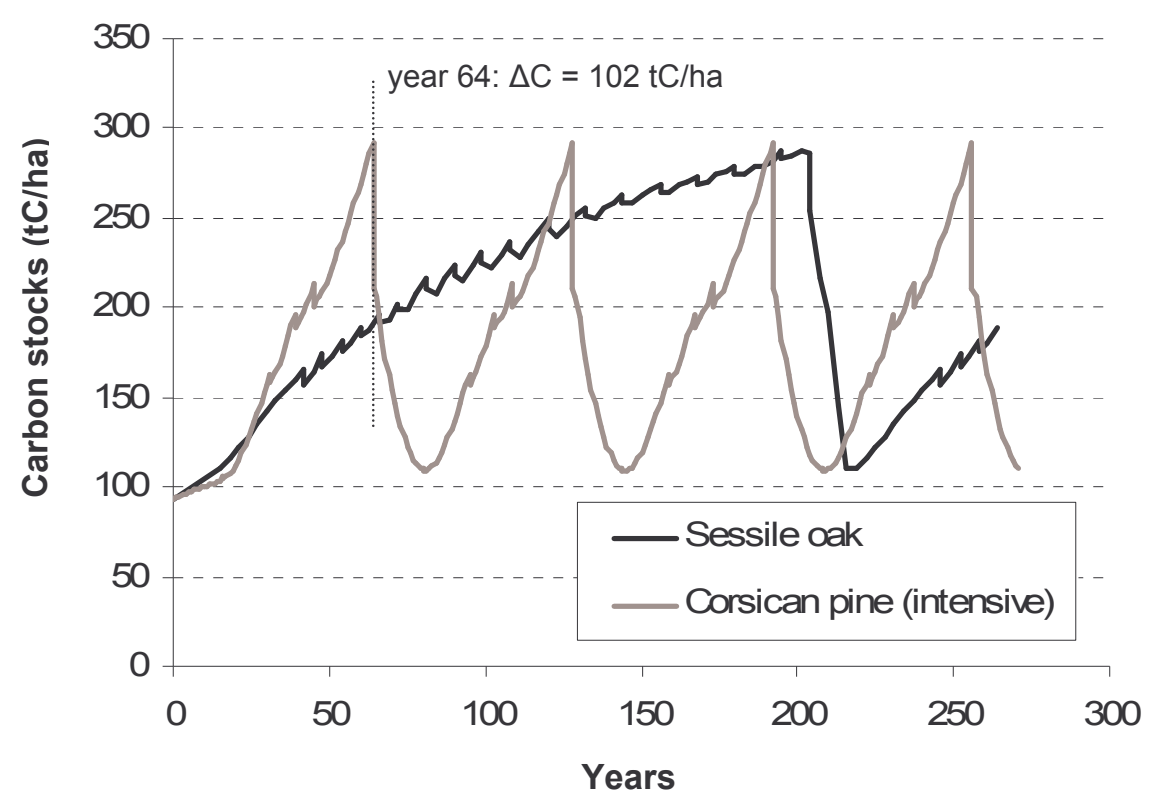

Figure 6: Evolution of carbon stocks for sessile oak and for Corsican pine after sessile oak substitution.

For Corsican pine, only the silviculture "intensive" is plotted.

The differential carbon stock at the end of the Corsican pine first rotation (64 years) is plotted. 


\begin{tabular}{ccc}
\hline $\begin{array}{c}\text { Site } \\
\text { type }^{(1)}\end{array}$ & $\begin{array}{c}\text { Number of } \\
\text { sessile oak stands clustered } \\
\text { by site type }\end{array}$ & $\begin{array}{c}\text { Sessile oak mean site } \\
\text { index }\left(H_{100}\right)^{(2)}\end{array}$ \\
\hline A2 & 1 & 26.7 \\
A4 & 8 & 21.7 \\
A8 & 6 & 22.0 \\
C4 & 2 & 24.4 \\
L1 & 1 & 22.3 \\
L2 & 37 & 25.2 \\
L3 & 64 & 25.9 \\
L4-L5 & 16 & 22.7 \\
L6 & 58 & 24.7 \\
L7a & 67 & 24.2 \\
L7b & 95 & 25.2 \\
S1 & 1 & 23.8 \\
S13 & 12 & 25.8 \\
S15 & 36 & 25.2 \\
S5 & 10 & 24.6 \\
S7 & 25 & 25.2 \\
S9-S11 & 1 & 12.4 \\
\hline
\end{tabular}

\begin{tabular}{cc}
\hline $\begin{array}{c}\text { Corsican pine } \\
\text { site index }\left(H_{30}\right)^{(1)}\end{array}$ & $\begin{array}{c}\text { Possibility to install a } \\
\text { Corsican pine stand }\end{array}$ \\
\hline 12.8 & Avoid \\
15.3 & Possible \\
16.2 & Possible \\
13.1 & Avoid \\
13.5 & Avoid \\
14.5 & Possible \\
14.6 & Possible \\
14.6 & Avoid \\
14.3 & Possible \\
15.7 & Possible \\
14.8 & Not possible \\
11.8 & Not possible \\
15.1 & Possible \\
15.5 & Possible \\
15 & Possible \\
15.5 & Avoid \\
14 & Possible \\
\hline
\end{tabular}

Table 1: comparison of site indices for Corsican pine and sessile oak stands in Centre and Pays de la Loire regions in France The sessile oak stands are clustered by station type of Gilbert et al. 1996 determination key

The highlighted line is the chosen site index couple for the study

${ }^{(1)}$ Information from Gilbert et al. 1996 determination key, ${ }^{(2)}$ Calculations from NFI data and Duplat and Tran Ha model (1997) 


\begin{tabular}{rcccccc}
\cline { 2 - 6 } & Age & $\begin{array}{c}\text { Number of } \\
\text { stems }\end{array}$ & $\begin{array}{c}\text { Dominant } \\
\text { height }(\mathrm{m})\end{array}$ & $\begin{array}{c}\text { Mean } \\
\text { diameter }(\mathrm{cm})\end{array}$ & $\begin{array}{c}\text { Dominant } \\
\text { diameter }(\mathrm{cm})\end{array}$ & $\begin{array}{c}\text { Basal } \\
\text { area }\left(\mathrm{m}^{2}\right)\end{array}$ \\
\hline $\begin{array}{r}\text { Sessile oak } \\
\text { silviculture }\end{array}$ & 204 & 82 & 37.1 & 70.7 & 70.7 & 32.2 \\
$\begin{array}{r}\text { Cors. pine } \\
\text { intensive silv. }\end{array}$ & 64 & 199 & 28.4 & 50.4 & 52.7 & 39.8 \\
$\begin{array}{r}\text { Cors. pine } \\
\text { structure silv. }\end{array}$ & 61 & 299 & 26.8 & 40.1 & 43.2 & 37.8 \\
\hline
\end{tabular}

Table 2: Main characteristics (per ha) of the stands at the time of final harvest estimated by growth models (Fagacées and $P N L$ ) 


\begin{tabular}{cccc}
\hline Species & Lignin/nitrogen & Compartment & Source \\
\hline Pedonculate oak & 23.6 & Litter shadow leaves & Sariyildiz and Anderson, 2003 \\
Pedonculate oak & 32.4 & Litter sun leaves & Sariyildiz and Anderson, 2003 \\
Sessile oak & 32.9 & Litter leaves & Cortez et al., 1996 \\
Oak mean value & $\mathbf{2 9 . 6}$ & & \\
\hline Cors. pine & 46.3 & Litter needles & Fioretto et al., 1998 \\
Cors. pine & 58.7 & Litter needles & de Santo et al., 2002 \\
Cors. pine mean value & $\mathbf{5 2 . 5}$ & & \\
\hline
\end{tabular}

Table 3: Values of lignin / nitrogen ratio found in a bibliography survey 


\begin{tabular}{cc}
\hline Kind of product & Lifespan of a log $(y r)$ \\
\hline Paper and board & 2 \\
Energy wood & 2 \\
Construction & 9.1 \\
Furniture & 8.5 \\
Handling & 3.9 \\
\hline
\end{tabular}

Table 4: Lifespan expectancy of a log assigned to one of a group of products, including the losses during first and second process, and including recycling. These are not the lifespans of final products. Construction includes wood for building structures, scaffolding, formwork...

Handling includes wooden pallets, wooden case, crates...

From Paquet and Deroubaix (2003), Selmani (1992) and Vallet (2005) 


\begin{tabular}{|c|c|c|c|c|c|c|c|c|}
\hline & & \multirow{2}{*}{\multicolumn{7}{|c|}{ Mean diameter of the $\log (\mathrm{cm})$}} \\
\hline & \multirow[b]{2}{*}{$\%$} & & & & & & & \\
\hline & & $70-79$ & $60-69$ & $50-59$ & $40-49$ & $30-39$ & $20-29$ & $10-19$ \\
\hline A : Slicing & 1 & $x$ & $x$ & $x$ & & & & \\
\hline B1: Cabinet working & 4 & & $x$ & $x$ & $x$ & & & \\
\hline B2 : Fine joinery & 10 & & & $x$ & $x$ & $x$ & & \\
\hline C1 : Ordinary joinery & 15 & & & $x$ & $x$ & $x$ & & \\
\hline C2: Framework, flooring & 15 & & & & $\mathrm{X}$ & $x$ & $x$ & \\
\hline$T:$ Sleepers & 10 & & & & $x$ & $x$ & & \\
\hline Energy / paper wood & 45 & & & & & & $x$ & $x$ \\
\hline
\end{tabular}

Table 5: Partition of a log between products based on mean diameter of the log for sessile oak The crosses mean that the type of $\log$ is in the product group

The percentages indicates the distribution of the national resource for oak From Flammarion (1986) 


\begin{tabular}{cccc}
\hline Quality & Joinery & Construction & Handling \\
\hline$O A$ and $O B$ & $100 \%$ & $0 \%$ & $0 \%$ \\
1 & $60 \%$ & $40 \%$ & $0 \%$ \\
2 & $40 \%$ & $60 \%$ & $0 \%$ \\
$3 A$ & $0 \%$ & $0 \%$ & $100 \%$ \\
\hline
\end{tabular}

Table 6: Corsican wood distribution between the different kinds of products function of the quality of the board

Notation 0A, 0B, 1, 2, 3A corresponds to the French standard NF B 52-001, $0 \mathrm{~A}$ is the best quality wood, $3 \mathrm{~A}$ the worst. 


\begin{tabular}{|c|c|c|c|c|}
\hline \multicolumn{2}{|c|}{ Model } & $\begin{array}{c}\text { Mean root } \\
\text { carbon content }\end{array}$ & $\begin{array}{l}\text { Ratio below/above } \\
\text { ground carbon content }\end{array}$ & $\begin{array}{c}\text { Mean total } \\
\text { carbon content }\end{array}$ \\
\hline \multirow{6}{*}{ 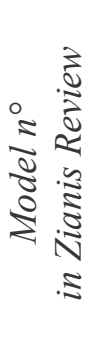 } & 450 & 11.4 & 0.20 & 175 \\
\hline & 451 & 23.4 & 0.41 & 187 \\
\hline & 453 & 5.6 & 0.10 & 169 \\
\hline & 454 & 6.2 & 0.11 & 170 \\
\hline & 455 & 20.3 & 0.36 & 184 \\
\hline & 456 & 9.0 & 0.16 & 173 \\
\hline \multicolumn{2}{|c|}{$\begin{array}{l}\text { Drexhage } 2001 \\
\text { (selected model) }\end{array}$} & 14.8 & 0.26 & 179 \\
\hline
\end{tabular}

Table 7: Results of the sensibility analysis on root biomass equation used on Corsican pine, simulations for the "intensive" silvicultural scenario. Mean carbon content values in tC/ha. 